\title{
Genetic Aspects of the Growth Curve Characteristics in Japanese Black Cows
}

\author{
Yasuhiko W ADA and Akira NiSHIDA \\ National Institute of Animal Industry, Tsukuba Norindanchi \\ P.O. Box 5, Ibaraki-ken 305
}

(Received May 14, 1987)

\begin{abstract}
BertalanfFy's growth function was fitted to body weight-age data from 203 Japanese Black cows to study the genetic aspects of growth curve parameters and derived traits. Data were collected at the Kagoshima Livestock Breeding Station of the Ministry of Agriculture, Forestry and Fisheries of Japan. Year of birth had statistically significant $(P<.05)$ effects on all growth curve characteristics. Dam age also significantly affected $(\mathrm{P}<.01)$ all growth curve characteristics except for the mature weight. Sire within year of birth affected $(\mathrm{P}<.01)$ the mature weight and the rate of maturing. Season of birth was an important source of variation $(\mathrm{P}<.01)$ in the rate of maturing. Least-squares means of calculating the mature weight increased with each year while those of the birth weight did not change. Consequently, least-squares means on the degree of maturity at birth decreased year by year. The heritability estimates of and standard errors in mature weight, the rate of maturing and the degree of maturity at birth were $.82 \pm .31,1.03 \pm .31$ and $.36 \pm .29$, respectively. The genetic correlation between mature weight and rate of maturing was - .64 .47. The rate of maturing and the degree of maturity at birth were positively correlated genetically. These results suggest that the selection for the shape of the growth curve is more difficult than the selection only for the growth rate, such as daily gain.
\end{abstract}

Jpn. J. Zootech. Sci., 58 (12) : 1078-1085, 1987

Key words : growth curve, mature weight, rate of maturing, Bertalanffy's model, heritabilities

Most genetic studies on the growth of beef cattle have concentrated on weaning weight, yearling weight and birth weight. These traits are the point evaluations of growth over a relevant economic time period. Recently, lifetime weight-age relationships have become subjects of major interest for some animal scientists and producers, since they have recognized the economic importance of mature size, rate of maturing and related characteristics ${ }^{1)}$. Nonlinear growth functions of BRODY ${ }^{2,3)}$, logistic ${ }^{4,5)}$, GOMPERTZ $^{6)}$, BERTALANFFY ${ }^{7,8)}$ and RICHARDS ${ }^{8-10)}$, have been used to describe the growth patterns of animals. An optimum growth curve could be obtained by selection for the desired values of growth curve parameters, Brown et al. ${ }^{3)}$ estimated heritabilities and genetic correlations via growth curve parameters, and showed that the estimates were different for the two breed groups. Therefore, it is necessary to 
estimate heritabilities and genetic correlations on growth curve parameters in Japanese Black cows. WADA et al. ${ }^{8)}$ found that BERTALANFFY's was the best model for describing weight-age data in Japanese Black cows. The relative importance of genetic and environmental effects were estimated via BERTALANFFY growth curve parameters and derived traits.

\section{Materials and Methods}

Source of Data The data were obtained from 203 Japanese Black cows raised at the Kagoshima Livestock Breeding Station of Ministry of Agriculture, Forestry and Fisheries of Japan. The cows were born between 1964 and 1981 and were grazed from May through November and raised in confinement from December through April. The heifers were fed creep and selected for large weaning weight and for high judging scores. The cows for herd replacement were selected based on reproductive and maternal performance. The cows were weighed at one month intervals from their day of birth up to six months of age, thereafter at two month intervals until 24 months of age, and further at 28,32 and 36 months of age.

Growth Model BertalanFFy ${ }^{7)}$ derived a general differential equation :

$$
d W / d t=\alpha W^{\frac{2}{3}}-\beta W
$$

This equation means that the change in body weight $W$ is given by the difference between the amount of anabolism $\alpha W^{\frac{2}{3}}$ and catabolism $\beta W$, where $\alpha$ and $\beta$ are constants. The solution of equation (1) for weight at months of age $t ; W_{t}$ is :

$$
W_{t}=A\left(1-B e^{-k t}\right)^{3}
$$

where $A=\alpha / \beta=$ mature weight, $B=$ constant of integration, $k=\beta / 3=$ rate of maturing. The curve has an inflection point at the time when $W$ reaches $29.6 \%$ of mature weight ( $W=0.296 A$ ). Equation (2) was fitted to the weight-age data series of each cow, and the parameters of $A, B$ and $k$ for each individual were estimated using a modified GaUSS-NEWTON iterative procedure developed by HARTLEY ${ }^{11)}$ for nonliear models. The initial values of iteration for each parameter were computed via WALFORD's graphic method ${ }^{12}$. Not only estimates of each parameter, but also the coefficient of determination which is a goodness-of-fit characteristic of the overall curve fit, was evaluated via the same computer program ${ }^{13}$. Degree of maturity at birth (the ratio of the estimated birth weight to the mature weight), age at inflection point, age at $90 \%$ maturity and estimated birth weight, were derived from BERTALANFFY's growth curve parameters.

Statistical Analysis The variance and covariance of growth curve characteristics were analyzed by the method of least-squares with a mixed model, and the variance and covariance components were estimated via Method III of Henderson ${ }^{14)}$. The analyses were done using the LSML 76 computer program coded by HARVEY ${ }^{15)}$.

The following statistical model was assumed :

$$
y_{i j k l}=\mu+B_{i}+s_{i j}+C_{k}+a X_{i j k l}+e_{i j k l}
$$

where

$$
y_{i j k l}=\text { the lth observation in the } i j k \text { th subgroup, }
$$




\section{WADA and NISHIDA}

$\mu=$ the overall mean, adjusted for the base of equal subclass frequencies when the age of dam is equal to the average,

$B_{i}=$ the effect of the $i$ th year of birth $(i=1,2, \ldots \ldots, 9)$,

$s_{i j}=$ the effect of the $\mathrm{j}$ th sire within the $\mathrm{i}$ th year of birth with mean zero and variance $\sigma_{\mathrm{s}: \mathrm{b}}^{2}$,

$C_{k}=$ the effect of the $\mathrm{k}$ th season of birth $(\mathrm{k}=1,2,3,4)$,

$\mathrm{a}=$ the linear partial regression coefficient of $y_{i j k l}$ on $X_{i j k l}$,

$X_{i j k l}=$ the deviation in age of dam from the arithmetic mean of the $X_{i j k l}$ and

$e_{i j k l}=$ the residual term, which is assumed to be normally and independently distributed with mean zero and variance $\sigma_{e}^{2}$.

Sire within year of birth and the residual were regarded as random effects, while all other effects were assumed to be fixed effects. Genetic parameters were estimated from paternal half-sib correlations. Standard errors of heritability and genetic correlation were estimated based on the modified formulae of SwIGER et al. ${ }^{16)}$ and TALLIS ${ }^{17)}$, respectively.

\section{Results and Discussion}

Growth Curve Fitting The fitting of BertalanfFy' s growth curve required an average 6.7 iterations for convergence. This model was well fitted to the weight-age data of Japanese Black cows and the average coefficient of determination was 0.973. Estimates of growth curve characteristics were almost normally distributed. The means and standard deviations for the growth curve characteristics are presented in Table 1. The mean of the mature weight in this study was smaller than that reported by WADA et al. ${ }^{8}$. This result might be caused by the genetic difference between the two herds analysed.

Analysis of variance The results of analysis of variance on the growth curve characteristics are presented in Table 2. Year of birth had a significant effects on all growth curve characteristics $(\mathrm{p}<.05)$. DeNISE and BRINKs ${ }^{10)}$ reported that year of birth was an important source of variation for the parameters $A, B$ and $k$ of BRoDy's model. Brown et al. ${ }^{3)}$ also reported that year of birth affected the parameters $A, B$ and $k$ of BRODY's model on Hereford and Angus females.

Changes in least-squares means of the mature weight are presented in Fig, 1. The least-squares means of the mature weight increased year by year. On the other hand,

Table 1. Means and standard deviations of growth curve characteristics

\begin{tabular}{ccll}
\hline \hline Trait & Mean \pm S. D. & Trait & Mean \pm S. D. \\
\hline A & $405.4 \pm 50.7$ & DMB & $.07161 \pm .01054$ \\
B & $.5857 \pm .0202$ & AIP & $4.979 \pm .945$ \\
k & $.1162 \pm .0175$ & A 90 & $24.94 \pm 3.96$ \\
& & EBW & $28.75 \pm 3.66$ \\
\hline
\end{tabular}

$\mathrm{A}:$ Mature weight, $\mathrm{B}:$ Constant of integration, $\mathrm{k}:$ Rate of maturing, DMB : Degree of maturity at birth, AIP : Age at inflection point, A90: Age at $90 \%$ maturity, EBW : Estimated birth weight 
Table 2. Analysis of variance on growth curve characteristics

\begin{tabular}{lrccc}
\hline \hline \multirow{2}{*}{$\begin{array}{l}\text { Source of } \\
\text { variation }\end{array}$} & & \multicolumn{3}{c}{ Mean squares } \\
\cline { 3 - 5 } & $\mathrm{df}$ & $\mathrm{A}$ & $\mathrm{B}$ & $\mathrm{k}$ \\
\hline Year of birth & 8 & $18353^{* *}$ & $.001359^{* *}$ & $.001497^{* *}$ \\
Sire within year & 47 & $2556^{* *}$ & .000384 & $.000403^{* *}$ \\
Season of birth & 3 & 1273 & .000002 & $.000947^{* *}$ \\
Age of dam & 1 & 166 & $.003091^{* *}$ & $.001613^{* *}$ \\
Error & 143 & 1396 & .000284 & .000190 \\
\hline
\end{tabular}

\begin{tabular}{llllc}
\hline \hline \multirow{2}{*}{$\begin{array}{l}\text { Source of } \\
\text { variation }\end{array}$} & \multicolumn{4}{c}{ Mean squares } \\
\cline { 2 - 5 } & DMB & AIP & A 90 & E BW \\
\hline Year of birth & $.000365^{* *}$ & $4.75^{* *}$ & $83.46^{* *}$ & $38.72^{*}$ \\
Sire within year & .000104 & $0.99^{* *}$ & $18.65^{* *}$ & $16.40^{* *}$ \\
Season of birth & .000001 & $1.72^{*}$ & $45.85^{* *}$ & 5.69 \\
Age of dam & $.000735^{* *}$ & $8.23^{* *}$ & $117.60^{* *}$ & $118.71^{* *}$ \\
Error & .000079 & 0.56 & 9.97 & 8.91 \\
\hline
\end{tabular}

$* * \mathrm{P}<.01$

$* \mathrm{P}<.05$

A : Mature weight, B : Constant of integration, $\mathrm{k}:$ Rate of maturing, DMB : Degree of maturity at birth, AIP : Age at inflection point, A $90:$ Age at $90 \%$ maturity, EBW : Es timated birth weight

the least-squares means of the degree of maturity at birth decreased year by year (Fig. 2). Namely, the mature weight of the cows born in 1964 and 1965 was $366.7 \mathrm{~kg}$ and their degree of maturity at birth was 0.079 . The cows born in 1980 and 1981 had a mature weight of $455.1 \mathrm{~kg}$ and a degree of maturity of 0.064 at birth. Average growth patterns of the cows born in 1964 and 1965 and in 1980 and 1981 are presented in Fig. 3. Fig. 3 shows the improvement in the growth rate caused by increments in mature weight. The change in the average growth curve might well be caused by the progress of both the feeding and genetic improvement of the herd.

Dam age also affected $(\mathrm{P}<.01)$ all characteristics except for the mature weight. Heifers calved by older dams had a larger rate of maturing, a larger estimated birth weight and a younger age at $90 \%$ maturity. Sire within year of birth affected $(\mathrm{P}<.01)$ the mature weight and the rate of maturing. Season of birth was an important source of variation $(\mathrm{P}<.01)$ in the rate of maturing, whereby cows born in summer and autumn showed a higher rate of maturing.

Genetic Analysis of Growth Curve Parameters

Heritability estimates for growth curve characteristics are presented in Table 3. The heritability estimate of mature weight, $.82 \pm .31$, was higher than that estimated by DeNISE and BRINKs ${ }^{10}$. The rate of maturing was also highly heritable, such as $1.03 \pm .31$. The heritability estimate of parameter $B, .40 \pm .29$, was similar to the estimates reported by DENiSE and BRINKS ${ }^{10)}$. BROWN et al. ${ }^{3)}$ reported heritability estimates of $A, B$ and $k$ as $.34 \pm .25, .62 \pm .34$ and $.33 \pm .25$, respectively, using 
WADA and NISHIDA

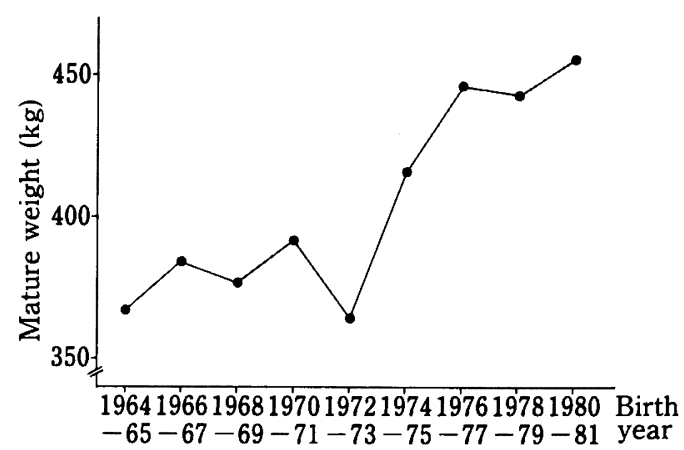

Fig. 1. Time trend in least-squares mean of the mature weight.

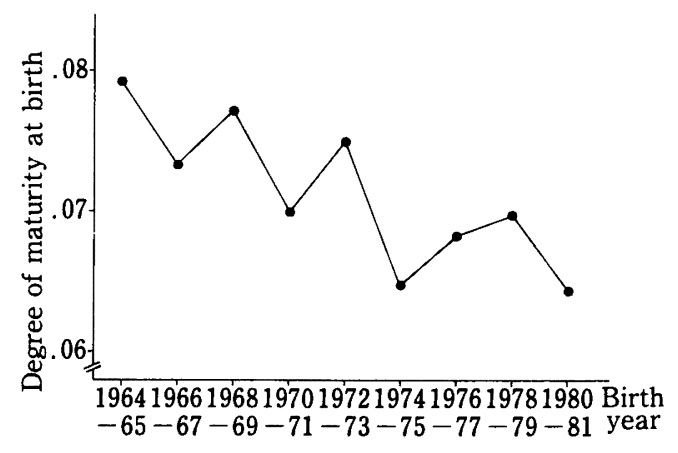

Fig. 2. Time trend in least-squares mean of the degree of maturity at birth.

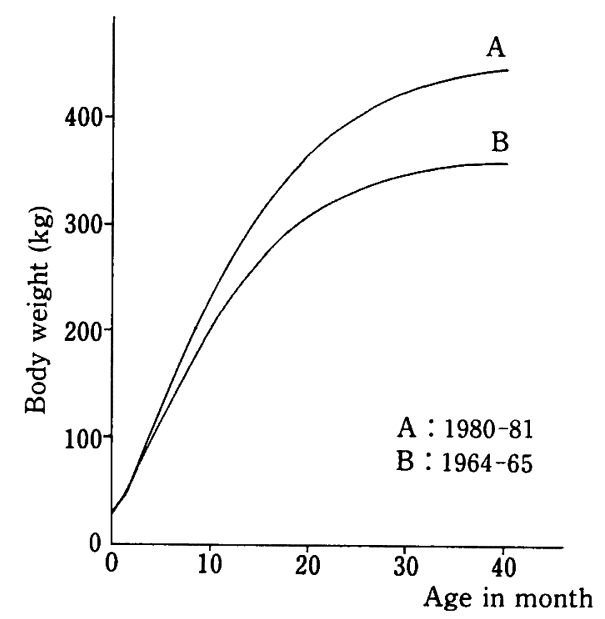

Fig. 3. Average growth patterns derived from least-squares mean of Bertalanffy's growth curve parameters. 
Growth Curve in Japanese Black Cows

Table 3. Estimates of heritability for growth curve characteristics

\begin{tabular}{cccc}
\hline \hline Trait & Heritability & Trait & Heritability \\
\hline A & $.821 \pm .307^{*}$ & DMB & $.358 \pm .290$ \\
B & $.398 \pm .292$ & AIP & $.780 \pm .306$ \\
k & $1.033 \pm .310$ & A 90 & $.851 \pm .308$ \\
& & EBW & $.828 \pm .307$ \\
\hline
\end{tabular}

*: Standard error

$\mathrm{A}:$ Mature weight, B : Constant of integration, $\mathrm{k}:$ Rate of maturing, DMB : Degree of maturity at birth, AIP : Age at inflection point, A90: Age at $90 \%$ maturity, EBW : Estimated birth weight

Table 4. Estimates of genetic and phenotypic correlation between growth curve characteristics

\begin{tabular}{crrrrrrr}
\hline \hline & $\mathrm{A}$ & $\mathrm{B}$ & $\mathrm{k}$ & $\mathrm{DMB}$ & $\mathrm{AIP}$ & $\mathrm{A} 90$ & EBW \\
\hline $\mathrm{A}$ & & .133 & -.635 & -.126 & .579 & .623 & .821 \\
$\mathrm{~B}$ & .507 & & -.531 & -.999 & .743 & .638 & -.482 \\
$\mathbf{k}$ & -.660 & -.414 & & .575 & -.947 & -.983 & -.203 \\
DMB & -.504 & -.996 & .404 & & -.773 & -.678 & .475 \\
AIP & .695 & .656 & -.927 & -.637 & & .989 & .020 \\
A 90 & .664 & .461 & -.972 & -.442 & .970 & & .116 \\
EBW & .339 & -.629 & -.154 & .625 & -.091 & .098 & \\
\hline
\end{tabular}

Genetic correlations are above diagonal and phenotypic correlations are below diagonal.

A : Mature weight, B : Constant of integration, $\mathrm{k}:$ Rate of maturing, DMB : Degree of maturity at birth, AIP : Age at inflection point, A90: Age at $90 \%$ maturity, EBW : Estimated birth weight

Hereford data. Standard errors of heritability estimates were large in this study and in other reports, because it was difficult to collect a large number of cows measured at regular intervals until mature age.

The genetic and phenotypic correlations between growth curve characteristics are presented in Table 4. The mature weight and the rate of maturing were negatively correlated genetically. This correlation indicates that the larger the mature weight, the greater rate of maturing. BRown et al. ${ }^{3)}$ and DENISE and BRINKs ${ }^{10)}$ also reported a negative genetic correlation between the mature weight and rate of maturing. EISEN et al. ${ }^{18)}$ fitted the logistic equation and found a negative genetic correlation between the two traits.

If we take BERTALANFFY's general formula (1), the negative correlation between the mature weight and the rate of maturing can be calculated on the assumption, $\mathrm{A}=\alpha / \beta$ and $\mathrm{k}=\beta / 3$. Therefore, we should improve not only $\beta$, the constant for anabolism, but also $\alpha$, the constant for catabolism, in order to improve the rate of maturing for the same mature weight. Some physiologists have measured the rate of breaking down in muscle by the $\mathrm{N}^{\tau}$-methyl histidine method. They reported that the rate of breaking down in muscle decreased with the age of the cattle ${ }^{19}$, while BERTALANFFY's general formula assumes a constant rate of breaking down. But, 


\section{WADA and NISHIDA}

BERTALANFFY's growth function (2) was well fitted to the weight-age data, so the negative correlation between mature weight and the rate of maturing is more reliable in our case.

The genetic correlation between the mature weight and estimated birth weight indicates that larger birth weights are associated with larger mature weights. The rate of maturing and the estimated birth weight were negatively correlated genetically. However the rate of maturing and the degree of maturity at birth were positively correlated.

BRown et al. ${ }^{3)}$ reported the genetic correlations between immature weights and the growth parameters in Herefords. The genetic correlations indicated that selection for heavier weights would have an adverse effect on the rate of maturing. Growth curves in Fig. 3 suggest that the improvement of the growth pattern in Japanese Black cows occurred via these correlations. Results of long-term selection experiments with mice indicate that the selections made for postweaning weight have little effect on the shape of the growth curve ${ }^{4}$. These results indicate that the selection made for the shape of the growth curve is more difficult to achieve than the selection for only the growth rate, such as daily gain.

\section{Acknowledgements}

The authors are grateful to the staff of the Kagoshima Livestock Breeding Station of the Ministry of Agriculture, Forestry and Fisheries of Japan for measuring and arranging the weight-age data.

\section{References}

1) Long, C.R., T.C. Cartwright and H.A. Fitzhugh, Jr., J. Anim. Sci., 40 : 409-420. 1975.

2) Brody, S., Bioenergetics and Growth. Reinhold Publishing Corp. New York. 1945.

3) Brown, J.E., C.J. Brown and W.T. Butrs, J. Anim. Sci., 34: 525-537. 1972.

4) Timon, V.M. and E.J. Eisen, Theor. Appl. Genetics, 39 : 345-351. 1969.

5) Mukai, F., Y. Wada, K. Namikawa and K. Tanase, Jpn. J. Zootech. Sci., 51 : 247255. 1980. (in Japanese)

6) LAIRD, A.K. and A. Howard, Nature, 213: 786-788. 1967.

7) Bertalanffy, L. von., Arch. Entwickmech. Org., 131 : 613-653. 1934.

8) Wada, Y., Y. Sasaki, F. Mukai and Y. Matsumoto, Jpn. J. Zootech. Sci., 54 : 46-51. 1983. (in Japanese)

9) Brown, J.E., H.A. Fitzhugh, Jr. and T.C. Cartwright, J. Anim. Sci. $42: 810-818$. 1976.

10) DeNise, R.S.K. and J.S. Brinks, J. Anim. Sci., 61 : 1431-1440. 1985.

11) Hartley, H.O., Technometrics, $3:$ 269-280. 1961.

12) WAlford, L.A., Biol. Bull. Woods Hoole, 90 : 141-147. 1946.

13) WADA, Y., Computer program library of animal breeding laboratory of Kyoto University, No. 5. 1982. (in Japanese)

14) Henderson, C.R., Biometrics, 9 : 226-252. 1953.

15) Harvey, W.R., User's Guide for LSML 76. Ohio State Univ. Columbus. 1977.

16) Swiger, L.A., W.R. Harvey, D.O. Everson and K.E. Gregory, Biometrics, 20 : 818 826. 1964. 
17) Tallis, G.M., Aust. J. Statist., $1: 35-43.1959$.

18) Eisen, E.J., B.J. Lang and J.E. Legates, Theor. Appl. Genetics, 39 : 251-260. 1969.

19) Harris, C.I. and G. Milne, Br. J. Nutr., 45: 411-422. 1981.

\title{
黒毛和種雌牛の発育様相形質についての遺伝学的性質
}

\author{
和田康彦・西田 朗 \\ 農林水産省畜産試験場, \\ 筑波農林研究団地，茨城県 305
}

黒毛和種䊒牛の経時的に測定された体重記録に BERTALANFFY の非線形発育モデルをあてはめて発育様 相形質を算出し，それらについて統計遗伝学的分析を行 なった．データとしては農林水産省宮崎種畜牧場鹿児島 支場で 1964 年から 1981 年の間に生産，育成された 203 頭の黒毛和種堆牛の体重記録を用いた. 分散分析の結果, 生れ年の勃果はすべての形質で有意性が認められた（P <.05). 母牛日龄への 1 次回帰む成熟体重を除くすべて の形質で有意性が認められた $(\mathrm{P}<.01)$. 生れ年内種雄 牛の効果は成熟体重と成热速度で有意性が認められ, 季
節の効果は成熟速度で有意性が認められた $(\mathrm{P}<.01)$. 生れ年別の最小自乗平均値は成熟体重で年々增加し, 生 時成熟度は年とともに減少していた. HENDERSON の方 法 3 で求めた遭伝率の推定值は成熟体重で. $82 \pm .31$, 成熟速度で $1.03 \pm .31$, 生時成熟度で. $39 \pm .29$ であっ た. また，成熟体重と成熟速度の間の遺伝相関は一. 64 \pm .47 と推定された．以上の結果より選抜によって成熟 体重を一定に保ちながら成熟速度を改良することは困難 であることが示唆された.

日畜会報， $58(12) ： 1078-1085,1987$ 